Jusmal lemiah


Vol. 6, No. 1, January 2018

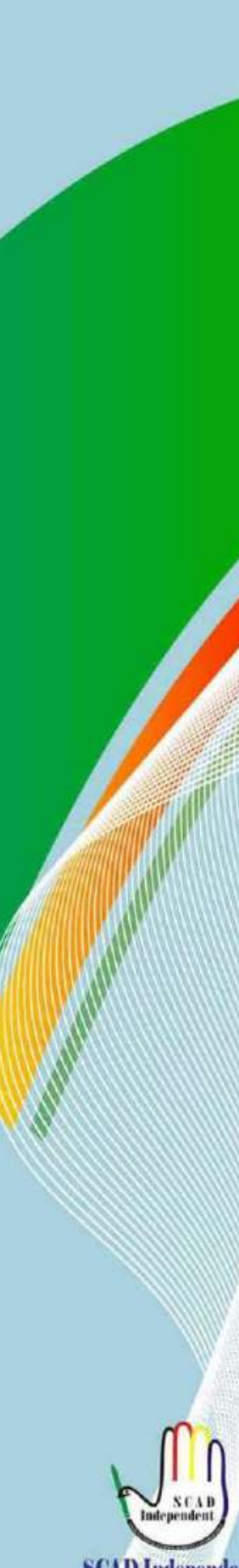

SCAI) Independent Accreditatioa by HO since 2014 $\bigodot$ Copernicus Publications

\section{III}

The Indonesian Journal of the Social Sciences www.journal.scadindependent.org Dot Prefix Number: 10.26811

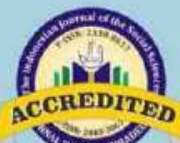

ACCREDITED - B" by the Ministry of Risteklikti from Oetaber 30, 2017 until Oetober 30, 2022

\section{Clarivate Analytics}

Emerging Sources Citation Index Web of Science ${ }^{\mathrm{TM}}$

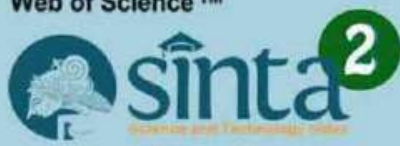
INDEX $\circledast$ COPERNICUS 


\title{
THE INFLUENCE OF ELECTION SUPERVISORY BEHAVIOR ON THE PERFORMANCE OF THE REGIONAL HEAD ELECTION ORGANIZER IN NORTH SUMATERA PROVINCE
}

\author{
Monang Sitorus \\ University of HKBP Nommensen, Medan, Indonesia \\ Contibutor Email: monangporsea@yahoo.com
}

Received: May 7, 2017

Accepted: Aug 12, 2017

Published: Jan 28, 2018

Article Url: http://journal.scadindependent.org/index.php/jipeuradeun/article/view/181

\begin{abstract}
The purpose of this research is to analyze the influence of behavior of regency/municipality election supervisor on the performance of the election organizer of a regional head (election) in North Sumatera Province. The basis of behavioral theory used in accordance with the phenomena observed in the field is the theory of behavior in which there are dimensions of encouragement, motivation, attitudes, and values with the originator of Mar'at. While the theory of performance using Ruky S Achmad's theory which includes dimensions of quality, quantity, timeliness, cooperation, and responsibility. The method used is survey method with a census. Then, the data is tabulated and analyzed using multiple regressions. The results showed that the biggest dimension of behavior contributing to the performance of the election organizer is the dimension of encouragement (X1) of 1,612, the value (X2) of 1.541, the motivation (X3) of 0.978 and the attitude (X4) of 0.803. While the determination coefficients test (R2) amounted to $83.4 \%$. Other undetectable factors ( $\varepsilon /$ epsilon) contributed to the election performance of $16.6 \%$.
\end{abstract}

Keywords: Election Supervisor, Performance, Behavior, Province of North Sumatra 


\section{A. Introduction}

General Elections such as the election of the regional head (Pemilukada) are a means of realizing the people's sovereignty in order to produce a democratic government. In accordance with the provisions of the 1945 Constitution, elections are run on the basis of Direct, General, Free, and Confidential, and Honest and Fair (Luber and Jurdil). According to the 1945 Constitution and Law No. 15 of 2011 on the Implementation of General Elections, elections are conducted by the General Elections Commission (KPU), supervised by the Election Supervisory Board (Bawaslu), both of which are national, permanent, and independent, and the Honorary Council Election Organizer (DKPP) which is responsible for maintaining and conducting elections that have independence, honesty, justice, legal certainty, order, public interest, openness, proportionality, professionalism, accountability, efficient and Effective. The implementation of the 12 dimensions is our common goal (das sollen). Even today's modern-day election campaigns of integrity are not only in countries that have been hit by political turmoil at home and abroad but has been the concern of the developed and developing countries including the United States, Germany, Britain, France, Japan, South Korea and others. Asshiddiqie, Jimly. (2014: 14). In order to make the 12th stronger, the Joint Regulation of KPU, Bawaslu and DKPP Number 13 The year 2012, Number 11 The year 2012 and Number 1 The year 2012 on the Code of Ethics of the Election Organizer shall be made.

If observed the implementation of the election of the regional head (Pemilukada) simultaneously has been regulated in Article 201 Paragraph 1-7 Law Number 8 The year 2015 on Amendment to Law Number 1 The year 2015 on Stipulation of Government Regulation in Lieu of Law No. 1 of 2014 on Election Governors, Regents and Mayors become Laws. This Act is designed to ultimately enable us to conduct simultaneous elections for the entire territory of the Republic of Indonesia in 2027 (the seventh phase). For the First Election in the first phase of Article 201 paragraph 1 has determined that the implementation is done in December 2015, exactly 9 December 2015, a total of 269 regions (9 Provinces, 36 Regencies, and 224 
Cities). Then the second phase held in February precisely 15 February 2017, as many as 101 consisting of 7 Provinces, 76 Districts and 18 Cities. While the third stage of 2018 will be implemented as many as 171 regions.

From a series of first round election of 2015 according to Outlook Book (2016: 133) facts in the field (das sein) the implementation of the election still leaves many problems that arise namely (1). Planning is that the formation of legislation is late (2). The administration is the determination of voters list (between ID and domicile) and the potential for sound bloat, registration, and determination of candidate pairs (3). Secretariat is that the conflict between commissioners with a secretariat, conflict of interest (4). Recruitment is the lack of human resources for PPS and KDP, PPS formation on the proposal with the Village Head or Village Head with BPD or Village Council, recruitment deadline (4). Finance/ budget is that most of the election budget is not included in the budget, the delay of disbursement of funds, the budget details are not in accordance with the standard cost of election spending (5). Socio-culture is utilizing the culture of a parcel in the moments of happiness, primordials and fanaticism (6) Geography is the difficulty of logistics distribution, access to information and limited transportation (7). The ceremony is to attend the invitation of candidate pairs that are private and limited, attend the invitation of candidate socialization of the candidates in a closed and incumbent entrust ASN to the regional secretary (Sekda). Above violations, of course, have an impact on the performance of the election organizers themselves both in terms of quality and quantity of the implementation of the election itself.

If it is observed, North Sumatera Province faced 74 complaints or $21.27 \%$ which were the most complaints of election violation in Indonesia after Papua about 36 complaints or $9.09 \%$ and East Java 31 complaints or $7.83 \%$. The complaint in the code of conduct of the election organizer is (1). Regional Election Commission (KPUD) / City, (2). Provincial Election Supervisory Board (Bawslu), (3). Members of the District Election Supervisory Committee (Panwaslu Kecamatan), (3). Field Election Supervisor (PPL), (4). Voting Committee (PPS). 
If it is examined the data recapitulation of cases handling alleged violation of the code of ethics by Council of General Election Organizer (DKPP) continue to increase significantly, especially the implementation of the election in North Sumatera. Based on data from Outlook 2016 Reflection and Projection of DKPP RI (2016: 17-18) the number of complaints in North Sumatera was as many as 59 people, and it is in the second place after West Kalimantan as many as 128 people, and the areas that receive the most sanction of permanent dismissal of election organizer from DKPP Is North Sumatra after Papua, and North Sumatra also receives the most admonished warning sanction for violating the code of ethics (Outlook 2016: 75-77). The regencies/ municipalities of election organizers in North Sumatra Province who got complaints were as many as 19 areas with 74 cases of complaints.

If observed the issue of election in North Sumatra Province based on the data above, of course, have an impact on the performance of election organizer. Such performance achievement is related to the number of voters entitled to exercise their voting rights with participation or voting rights. The performance achievement of election organizers in North Sumatra Province can be presented in the following table:

Tabel 1.2.

The number of Voting Participants with voting rights 2015-2016

\begin{tabular}{|c|c|c|c|c|c|c|c|}
\hline \multirow[t]{2}{*}{ No. } & \multirow{2}{*}{$\begin{array}{l}\text { Regency/ } \\
\text { Municipality }\end{array}$} & \multicolumn{2}{|c|}{ Total } & \multirow[t]{2}{*}{ No } & \multirow{2}{*}{$\begin{array}{c}\text { Regency/ } \\
\text { Municipality }\end{array}$} & \multicolumn{2}{|c|}{ Total } \\
\hline & & Voters & $\begin{array}{c}\text { Voting } \\
\text { Right } \\
\text { Participants }\end{array}$ & & & Voters & $\begin{array}{c}\text { Voting } \\
\text { Right } \\
\text { Participants }\end{array}$ \\
\hline 1 & Asahan & 516.282 & 286.500 & 11 & Nias Selatan & 211.287 & 132.601 \\
\hline 2 & Binjai & 189.607 & 126.367 & 12 & Nias Utara & 87.458 & 61.134 \\
\hline 3 & $\begin{array}{l}\text { Gunung } \\
\text { Sitoli }\end{array}$ & 87.361 & 55.919 & 13 & $\begin{array}{l}\text { Pakpak } \\
\text { Bharat }\end{array}$ & 33.091 & 27.594 \\
\hline 4 & $\begin{array}{l}\text { Humbang } \\
\text { Hasundutan }\end{array}$ & 131.051 & 96.959 & 14 & $\begin{array}{l}\text { Pematang } \\
\text { Siantar }\end{array}$ & 189.255 & 117.047 \\
\hline 5 & $\begin{array}{l}\text { Labuhan } \\
\text { Batu }\end{array}$ & 294.561 & 188.928 & 15 & $\begin{array}{l}\text { Serdang } \\
\text { Bedagai }\end{array}$ & 474.218 & 286.499 \\
\hline 6 & $\begin{array}{l}\text { Labuhan } \\
\text { Batu Selatan }\end{array}$ & 210.130 & 157.542 & 16 & Sibolga & 63.553 & 45.724 \\
\hline 7 & $\begin{array}{l}\text { Labuhan } \\
\text { Batu Utara }\end{array}$ & 233.362 & 172.248 & 17 & Simalungun & 657.483 & 354.082 \\
\hline
\end{tabular}


Monang Sitorus

\begin{tabular}{|l|l|l|l|l|l|l|l|}
\hline 8 & $\begin{array}{l}\text { Mandailing } \\
\text { Natal }\end{array}$ & 329.697 & 189.477 & 18 & $\begin{array}{l}\text { Tapanuli } \\
\text { Selatan }\end{array}$ & 212.321 & 154.793 \\
\hline 9 & Medan & $\begin{array}{l}1.961 .47 \\
1\end{array}$ & 527.206 & 19 & Tobasamosir & $\begin{array}{l}130.94 .3 \\
64\end{array}$ & \\
\hline 10 & Nias & 86.287 & 55.469 & \multicolumn{3}{|l}{} \\
\cline { 1 - 5 }
\end{tabular}

Source: Situng Pilkada KPU, 2016

This study aims to reveal, analyze, and measure the magnitude of the influence of election Supervisory (Panwaslu) behavior on the performance of the Provincial Head election in North Sumatra Province. In addition, to gain knowledge and understanding of the magnitude of influence of election Supervisory (Panwaslu) behavior on the performance of the Provincial Head election in North Sumatra Province.

\section{B. The Concept of Conducting the General Election}

The behavior of election organizers is closely related to ethics, deeds, morality, whether to distinguish right from wrong. As Saefullah (2007: 151) points out that human behavior is closely related to ethics, ethics is the doctrine of human behavior to be able to discern what is right and what is wrong. That is, what is good to do and wrong is to be avoided or not done. In the everyday sense, it is when connected with the manners of human association.

To facilitate an understanding of individual behavior there are several behavioral models designed by behavioral experts. This behavior model needs to be understood by the leader. These behavioral models are a way of understanding the reality of behavior, or the purpose of understanding the model according to Winardi (2005: 148) is to understand reality by organizing and simplifying it. So the model represents reality, but it is not a reality ". Behavioral models are not just one; there are various kinds according to the creator's frame of mind. The model is (1). Mar'at's model of behavioral (1981); (2). The behavioral model of Andreas A. Danandjaja (1986); (3). Model behavioral design by McShane. At.al. (2005).

From the three models, the behavioral model used as the analytical blade in this study is the theory of behavior created by Mar'at (1981). The 
consideration using this theory, first, Mar'at's behavioral theory (1981) contains a value system, where values indicate the consistency of individual behavior, consisting of consistent motivation, attitude, and culminating in the "value system". The inclusion of the value system element by the author is very important to understand the behavior of individuals, as disclosed by experts such as Winardi (2006: 66); Rosadi (1997: 40); Nazsir (1997: 72); Adiwisastra (1996: 52); Rusli (2000: 98).

Therefore, understanding the philosophical framework of human behavior must incorporate value elements as a pillar, or without understanding the value to understand individual behavior is false. This is reinforced by Siagian (1995: 110) saying that "the understanding of the real value system lays a solid foundation for understanding attitudes, motivations and behaviors." The strong opinions of the experts above include an element of value to understand individual behavior reinforces the belief of researcher to use the theory as its analytical blade.

Secondly, in accordance with the phenomenon found in the Regency/Municipality Election Supervisory Circle, the presence of "attitudes" of supervisors slows down electoral services, because among supervisors still appears the term "if it can be slowed down why accelerated", of course, the attitude of the employee will result in the election performance not yet optimal. The attitudes of the election supervisory officers are apparent from the determination of voter lists (between ID and domicile) and the potential for vote inflection, registration, and determination of candidate pairs of parties) as well as social-body that is utilizing the parcel culture on the moment of happiness, primordialism and fanaticism. That attitude is part of Mar'at's (1981) behavior.

More details of how human behavior is formed can be seen in the chart given by Mar'at (1981: 11) as follows: 


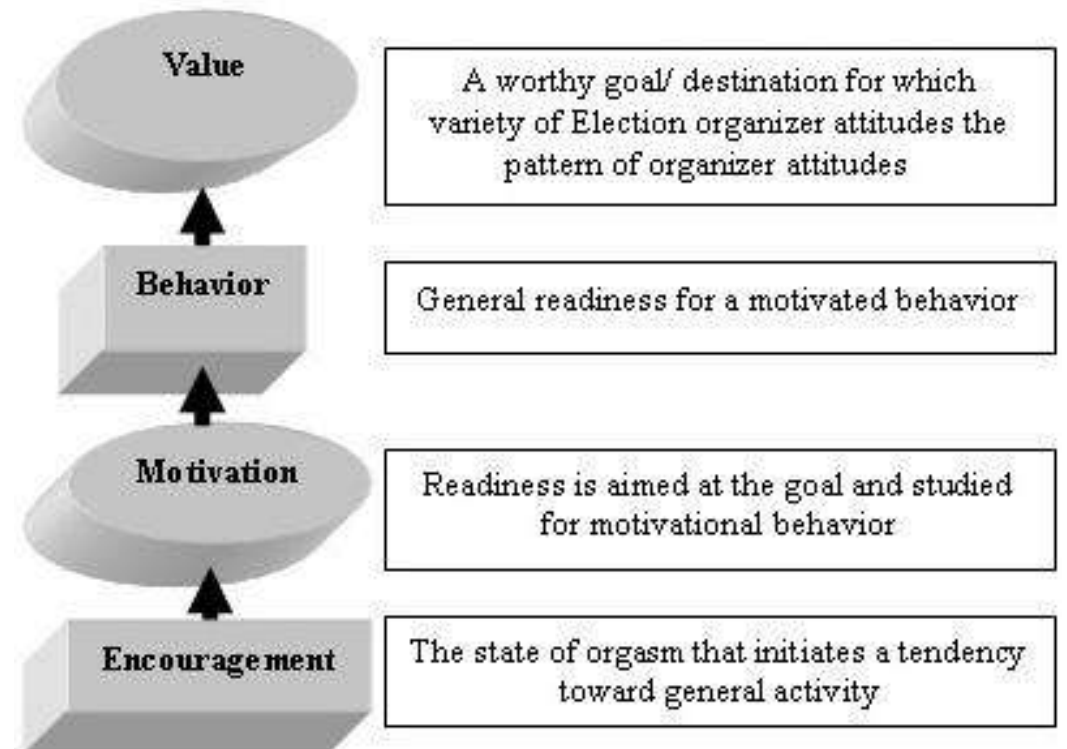

Figure 2.1. : Correlation between Encouragement, Motif, Behavior, and value

When examining the model of behavior formation in figure 2.1 above, encouragement is the main foothold, then the formation of motivation, and motivation bear one's attitudes, and one's attitude culminates in a person's value. That is, a well-behaved person will culminate in a person's value. The four factors that determine the behavior of individuals have a relationship with each other or an intact link. More details on the four factors that determine the behavior will be described further, namely:

\section{Encouragement}

Encouragement of each individual is usually generated by the result of physiological deficiencies so that efforts need to be done to maintain the physiological state that exists within man, as disclosed by Winardi (2012: 6) that in general individuals act because of a number of encouraging forces that exist in themselves, that power is generally related to needs, or wants, or fears. Zainun (2004: 20) says that drive encouragement is a boost within a person. That is, encouragement is a driving machine that exists in the human being due to the unmet need; the impulse is at the same time a force of stimulation within the internal self. 


\section{Motivation}

Looking at the behavioral model proposed by Mar'at (1981) encouragement is an early foothold for development and continues to motivation. This is also affirmed by Robert Bollles (in Koeswara, 2009: 65) that encouragement is considered to be adequate to explain motivation than instinctual theory since the concept of encouragement is more readily researched and easy to use to understand the motivation.

If you examine the above opinion, motivation is an external stimulus that can give person strength or become a driver, and the nature is external forces such as monetary rewards and non-monetary rewards such as promotion, or motivation can also be positive or negative in the form of rewards and punishment (Rewards, recompenses, and punishments).

Therefore, every electoral leader must recognize that a person enters an electoral organization in addition to an inner impulse, therefore salary or reward is the key to a positive value of motivating employees (Schermenhorn and Osborn (2003: 442).

\section{Attitude}

Mar'at (1981: 11-12) reveals that: "operationally attitudes can be seen from the existence of" predisposition "or" tendency "or predisposition, and then the predictable behavior of what happens when it is known". Because attitudes are often referred to as tendenciestendencies or tendencies. Furthermore, Mar'at (1981: 13) says attitude contains three components, namely (a). Components of cognition associated with beliefs, ideas, and concepts. (b). Affective component (affective) that concerns one's emotional life. (C). Components of conformity are the tendency to behave. The three components are not stand alone or are intact links, where the component of cognition is what is thought (which is related to the mind), or perceived about the object.

\section{Value}

Mar'at (1981: 11) reveals "that the development of selection and degeneration of individual behavior stems from drives and ultimately culminates in values. Or value is the final desire or the final hope of various 
circumstances or conditions. Sumantri (2001: 52) states "value is the basis of an individual's view of everything; the individual will use it to provide right or wrong judgment, good and bad, fair or unnatural, appropriate or inappropriate to something". Thus the value embedded in the concept of the individual will be used as a guide to compare, judge, decide and take action. Therefore values are closely related to one's attitude toward the observed object. Therefore, values indicate the consistency of the behavior of each individual. That is, the accumulation of electoral supervisory formation culminates in a shared value system, one having a visible value from its behavior.

\section{Performance Concepts}

Performance benchmarks are a measure of success achieved in every person or work unit within an organization. To know the measurement of success, it can be seen from the quantity, quality, and efficiency. While Thomson (1999: 201) says that: "Performance is the capacity that refers to employees' natural abilities and attributes, which enable them to perform job-related duties. Knowledge and skill refer to those things that can be taught that enable employees to perform their jobs effectively ".

Ruky S Achmad, (2002: 361) said that the performance of a person can be measured based on 5 (five) criteria resulting from the work of the individual employee/individual. The five criteria are quality, quantity, timeliness, cooperation, and responsibility. Therefore, in order for a person to perform high both in quality and quantity according to experts such as Veithzl Rivai, Masri Mohd (2008: 15-16) is largely determined by ability (A), motivation $(\mathrm{M})$ and opportunity $(\mathrm{O})$ or performance $=\mathrm{f}(\mathrm{A} \times \mathrm{M} \times \mathrm{O})$. While Terence R. Mitchell (1985: 391) said good performance can be determined by two dimensions of ability or ability $(A)$, motivation $(M)$ or performance $=f(A$ $x \mathrm{M})$. Ability without motivation or motivation without ability, both cannot produce a good performance achievement. It is based on two assumptions. The first assumption is that employees actually know what they should be doing, but they do not care. The second assumption is that employees work hard but unfortunately they do not have an adequate capability. Both are conditions that cause their performance is not optimal (Mitchell, 1985: 231). 


\section{Research Methods}

This research uses quantitative design with explanatory survey method because its purpose is to test the hypothesis. Populations and samples are District/ City Election Supervisors who have complaints when elected during the Year 2015-2016 in North Sumatra Province. The numbers of District/ City Election Supervisors in trouble are from 19 regions with the number of Election Supervisors each region as many as 3 (three) people or approximately are 57 Panwaslu. Because of the small number of population, the respondents are taken by the census.

To test the hypothesis the researcher uses the method of analysis of "double regression" with the formula $Y=a+b 1 \times 1+b 2 \times 2+b 3 \times 3+b 4 \times 4+$ $\varepsilon$. Before using the multiple regression tests, the classical assumption test is done. The test criteria are as follows: (1). Ho: $b i=0$, there is no positive and significant relationship of each dimension $(X 1=$ impulse, $X 2=$ motivation, $\mathrm{X} 3=$ attitude and $\mathrm{X} 4=$ value to the performance of election organizer $(Y)$. (2) Ha: $b i \neq 0$, there is a positive and significant relationship of each variable $(X 1, X 2, X 3, X 4)$ to the dependent variable $Y$. The criterion of decision making rejection and acceptance: (a) If tcount $>$ ttable then Ha is accepted and Ho is rejected (b).If tcount <ttabel then Ho is accepted and Ha is rejected. Furthermore, hypothesis testing simultaneously with the decision if (a).Fcount $>$ Ftable then Ha is accepted and Ho is rejected (b). Fcount $<$ Ftabel then Ho accepted and Ha rejected.

\section{Research Findings}

Indonesia has 34 provinces and North Sumatera Province is one of the neighboring province of Aceh and Riau Province. The province of North Sumatra has 33 districts/cities. From 33 districts/cities as many as 19 areas faced the issue of elections in 2015. Double regression results indicated encouragement $(\mathrm{X} 1)$ has a score $=1.612$. That is, if there is a strong force within the election organizer of one unit, for example, the drive to succeed while the other independent variable remains then the performance of the election organizers will experience an increase of 1,612. Motivation (X2), had a score of 0.978 . That is if there is external 


\section{Monang Sitorus}

motivation conducted by the leadership of one unit such as giving praise or awards while other independent variables remain the same then the performance of election organizers will experience an increase of 0.978 . Attitude (X3) had a score of 0.803 . That is if there is a positive attitude from election organizers of one unit such as discipline, etiquette while other independent variables remain the same then the performance of election organizers will experience an increase of 0.803 . The value (X4) had a score of 1.541. That is, if there are good and correct values when performing tasks such as the registration of the Permanent Election List (DPT) from the election organizer of one unit while the other independent variable remains the same then the performance of the election organizers will increase by 1,541 .

While the coefficient of determination tests (R2) was $83.4 \%$. That is, the variation of performance variable of election organizer in North Sumatera Province can be explained by the variation of motivation, attitude and value variable was $83.4 \%$. While the remaining undetected ( $\varepsilon /$ epsilon) contributing to the election performance of $16.6 \%$ is explained by variations of other variables that are not examined such as surveillance, work ethic, and others. Furthermore, when examined the magnitude of the contribution of these four dimensions to the performance of the election organizers reflects that the use of multiple regression is very good applied in this study.

Furthermore, the result of hypothesis testing partially or one by one based on t-student distribution table for $\alpha=5 \%$ and degrees free (57-3-1) obtained $\mathrm{t}$ table score $=1.67412$. Furthermore, if the calculation is done, where the score of tcount of encouragement variable is 2,100 while $t$ table equal to 1669. Because $t$ count is greater than $t$ table then it is concluded there is an encouragement relationship to the performance of election organizers in the Province of North Sumatra. This proves that the first hypothesis testing proposed by the researcher can be accepted and supported by the data. Furthermore, if the calculation is done where the score of $t$ count of motivation variable is 2.126 while $t$ table is 1.669 because $t$ count is greater than $t$ table then it is concluded there is a relationship of motivation to the performance of 
election organizers in North Sumatra Province. This proves that the second hypothesis testing proposed by the researcher can be accepted and supported by the data. Furthermore, if the calculation is done where the score of $t$ count of attitude variable is 2,073 while $t$ table equal to 1669 because $t$ count is bigger than $t$ table hence it can conclude there is the relation of attitude toward the performance of election organizer in North Sumatera Province. This proves that the third hypothesis test proposed by the researcher can be accepted and supported by the data. Then the calculation where the score of $t$ count of the value variable is 2,078 while $t$ table is 1669 because $t$ count is greater than $t$ table it is concluded there is a relationship value to the performance of election organizers in the Province of North Sumatra. This proves that the fourth hypothesis test proposed by the researcher can be accepted and supported by the data. If hypothesis testing is done with motivation, attitude and value simultaneously have positive and significant influence on the performance of election organizer in North Sumatera Province where F test count is 80,439 while $\mathrm{F}$ table is 2.50 , because $\mathrm{F}$ count $>$ from $\mathrm{F}$ table means that encouragement, Motivation, attitudes, and values simultaneously have a positive and significant influence on the performance of election organizers in North Sumatra Province.

\section{E. Discussion}

If the highest scores contribute to the performance of the election is the dimension of encouragement with a score of 1612. This reflects that the motivation is the key point and the most basic form of election organizer behavior. That is, encouragement is a driving machine that exists in the human being due to the unmet need; the encouragement is at the same time a force of stimulation within the internal self. Although insufficient incentives are given by the leader, if there is an inward drive to work seriously then incentives are not a barrier to work.

Then the value dimension also contributes as a second point to the performance of the election with score system of 1,541. That is, a person's shared value system is the existence of a person to provide the "right and true", "appropriate and inappropriate" or anything evaluative to act primarily in providing election services. Therefore, the election organizers 
are valuable when it can distinguish good and bad, right and wrong. Therefore, the value system is very important to be taken into account in the process of creating the behavior of the electoral officer.

It should be understood that always tempt man there are three "ta" that make his behavior deviated from the norm namely "Throne, Treasure, Woman". Assuming the term of the great thinker of the world (philosopher) Aristotle says a man is a homo politico (a political being who always hungers for power, or throne then becomes the first "ta." Karl Marx says a man is homo economics (economic beast who never tired of chasing money or treasure then is the second "ta." While psychologist Sigmund Freud says humans are homo Sextus, that in man, sex drive is the most passionate throughout his life or woman then it becomes third "ta". These third comes from within Human self, and difficult to guess, but visible from attitude (deeds), while the first and second ta come from outside the human self.

Thus, the function of value is as a driver and as well as limiting human actions. Clearly, something considered valuable to the individual, then it will be used as the basis for individuals to achieve or do something and as a guideline for not doing something harmful to individuals or others. Actually, if likened to an ethical election organizer such as a "railroad" that has stable compartments, bundled, permanent, written, sanctioned, transparent, measurable, fair, and contained value system as the basis of a moral standard that must be maintained by the election organizers so that the train can go faster by bringing people into the voice of the people as a desirable goal. This is what election supervisors need to build as election organizers. Election participants and organizers should avoid inadvertence and black campaign. The agreements not only avoid black campaign but also prevent fraud (Sitorus, Sinar Indonesia Baru 7 September 2014).

In fact, the behavior of election organizers is basically formed after passing through the whole activities, i.e. elements of interests or goals, needs, desires, motivations and attitudes of a person. Therefore, "it is the behavior that is observed to bring elections with integrity" (Sitorus, 2015: 17). The behavior of a person is influenced by internal and external factors according to his / her interests, for example, ASN becomes a successful candidate team so he/she forgets unconsciously violates ethics. 
If it is traced etymologically, ethic comes from the Ancient Greek "ethos" which means the fence of livestock to keep the cattle from wandering around casually. Although the gate is not locked the cattle that are in the circle of the fence do not dare to exit the fence. Ethical and moral electoral organizers will perform their actions in accordance with agreed norms or rules and endeavor to respect and maintain them such as Joint Regulations of the KPU, Bawaslu and DKPP Number 13 of 2012, Number 11 of 2012 and No. 1 of 2012 on the Code of Conduct for Election Organizer. Ethics must be prioritized and become a mentor in every state and nation activity.

There are several areas of ethics that have developed in practice in the adult world as proposed by Asshiddiqie (2014; 15) namely (1). Economic ethics, (2). Bio-ethics (bioethics), (3). Ethics of technology, (4). Environmental ethics, (5). Social ethics, organizational ethics, and professional ethics and (6). Public sector ethics. Certainly, in this paper, public sector ethics is as an organizer of the election state in the broad sense that includes all aspects of the system of ethical norms that bind and guide for the organizers of state power as a whole. Therefore, a person who possesses ethics does not suddenly change, that is, another day, tomorrow or another day after another is said but done differently. How important the behavior as a guide in everyday life, behavior now continues to experience the development of even unstoppable in the life of nation and state.

Furthermore, when observed the third order score is motivation with a score of 0.978 . That is, the motivation given by external leaders such as giving praise, rewards or punishment will be able to shape the behavior of election organizers. Although the motivation is temporary but cannot be ignored in the formation of conducive behavior. Therefore, the leaders of election organizers must realize that someone enters the electoral organization in addition to the encouragement from within a person, then the leader as a motivator must be able to provide outside stimulation to meet individual needs. If a person's needs are not met by the institution he/she enter then will find a side job. In fact, from the negative side, they will receive money from election participants with promises to be won in the election. 
When observed the fourth order score is the attitude dimension (X3) with a score of 0.803 . That is, attitudes should not be ignored in the formation of the conduct of election organizers. A person who is unhappy about the work was done will be visible from his attitude that he/she is rarely or lazily coming to work or often too late. Because the attitude is often referred to "tendencies" that someone acted. Leaders must firmly shape the conduct of election organizers, with a firm attitude from the leaders, thus it will be able to shape the attitudes of his followers. Election organizers who often come late to the office, late to make a report then the leaders must provide a firm reprimand to better the organizer's attitude. Therefore, a leader as proposed by Andrie (2015: 231) says followers' behavior must be understood by every leader both in terms of attitude and motivation but must be linked to the worker's own daily reality.

\section{F. Conclusion}

The behavior of the election organizers in which the encouragement, motivation, attitudes, and values have a strategic role and have a positive and significant influence both partially and simultaneously on the performance of election organizers in North Sumatra Province. That is, if you want to improve the performance of election organizers, especially in North Sumatra Province then the organizer's behavior along with dimensions must be managed properly.

\section{Bibliography}

Achinike, H., \& Ogbonna, S. (2016). Federalism Critical Arguments as The Transfigurations of Nigerian Federalism. Jurnal Ilmiah Peuradeun, 4(3), 369-382.

Adiwisastra, Josy. (1996). Pengaruh Pelaksanaan Program Keluarga Berencana Terhadap Perubahan Nilai Anak Pada Orang Sunda di Kabupaten Subang. Bandung : PPS Universitas Padjadjaran.

Andrie. (2015). Pengaruh Kepemimpinan dan Motivasi terhadap Kepuasan Kerja dalam meningkatkan kinerja pegawai di Komisi Pemilihan Umum Daerah seKepulauan Nias. Jakarta : Pascasarjana Universitas Terbuka. 
Asshiddiqie, Jimly. (2014). Kuliah Etika, Memahami dan Menerapkan Sistem Etika Dalam Praktik Kehidupan Sosial. Newsletter DKPP Edisi 5. II. Mei.

Asshiddiqie, Jimly. (2014). Kuliah Etika, Menegakkan Sistem Norma Agama, Etika dan Hukum. Newsletter DKPP Edisi 6. II. Juni 2014.

Barker, C.; Pistrang, N.; and Elliott, R. (2002). Research Methods in Clinical Psychology: An Introduction for Students and Practitioners, $2^{\text {nd }}$, John Wiley \& Sons, Ltd. England.

Beer, C. (2015). Democracy and Gender Equality. Jurnal Ilmiah Peuradeun, 3(2), 323-342.

Danandjadja Andreas.A. (2006). Sistem Nilai Manajer Indonesia Tinjauan Kritis. Berdasar Penelitian. Jakarta : PPM

Dewan Kehormatan Penyelenggara Pemilu RI. (2016). Outlook Refleksi dan Proyeksi Untuk Kemandirian, Integritas dan Kredibilitas Penyelenggara Pemilu. Jakarta: DKPP RI.

Haynes, J. (2015). Religion in Global Politics: Explaining Deprivatization. Jurnal Ilmiah Peuradeun, 3(2), 199-216.

Hersey, Paul \& Kenneth H. Blanchard. (2009). Terjemahan Agus Dhanna, Pusdiklat Depdikbud, Manajemen Perilaku: Organisasi Pendayagunaan Sumberdaya Manusia. Jakarta: Erlangga.

Idris, S. (2014). Demokrasi dan Filsafat Pendidikan (Akar Filosofis dan Implikasinya dalam Pengembangan Filsafat Pendidikan). Ar-Raniry Press.

Idris, S., \& Tabrani, Z. A. (2017). Realitas Konsep Pendidikan Humanisme dalam Konteks Pendidikan Islam. JURNAL EDUKASI: Jurnal Bimbingan Konseling, 3(1).

Islamy, Irfan.H., (2009). Prinsip-Prinsip Perumusan Kebijaksanaan Negara. Jakarta: PT Bumi Aksara.

Koeswara. E. (2009). Motivasi Teori dan Penelitiannya. Bandung: Angkasa

Mar'at. (1981). Sikap Manusia Perubahan serta Pengukuran. Jakarta : Ghalia Indonesia.

Mc Shane, Steven, L., Glinow Von Mary, Ann, (2005). Organizational Behavior. Boston: Mc Graw-Hillim.

Moch. Nurhasim, (ed.). (2014). Partisipasi Pemilih Pada Pemilu 2014 Studi Penjajakan. Pusat Penelitian LIPI kerjasama dengan KPU RI. 
Peraturan Bersama KPU, Bawaslu dan DKPP Nomor 13 Tahun 2012, Nomor 11 Tahun 2012, dan Nomor 1 Tahun 2012 tentang Kode Etik Penyelenggara Pemilu.

Rivai, Veithzal, (2008). Manajemen Sumber Daya Manusia Untuk Perusahaan, Raja Grafindo, Jakarta.

Rosadi Dedi. (1997). Sistem Perencanaan Terpadu Sebagai Salah satu Determinan Peningkatan Pendapatan Asli Daerah dari Sektor Pajak. Bandung: PPS Universitas Padjadjaran

Ruky Achmad.S. (2002). Sistem Manajemen Kinerja. Panduan Praktis untuk Merancang dan Meraih Kinerja Prima. Jakarta : Gramedia

Rusli, Budiman. (2000). Pola Kebijakan Publik Tentang Kerjasama Antar Pemerintah Kotamadya dan Kabupaten Daerah Tingkat II Cirebon Dalam Pembangunan Prasarana Kota Terpadu Cirebon Raya. Bandung : PPS Universitas Padjadjaran.

Saefullah. (2007). Pemikiran Kontemporer Administrasi Publik Perspektif Manajemen Sumber Daya Manusia Dalam Era Desentralisasi. Cetakan pertama. Bandung : LP3AN FISIP UNPAD.

Schermerhorn Jhon R., Hunt James and Osborn Richard N. 2005. Organizational Behavior. United State of America: Jhon Wiley \& Sons Inc.

Sedarmayanti, (2007). Manajemen Sumber Daya Manusia Reformasi Birokrasi dan Manajemen Pegawai Negeri Sipil. Bandung: PT Refika Aditama.

Siagian. (2005). Motivasinya dan Aplikasinya. Jakarta : Rineka Cipta.

Sitorus, M. (2008). Pengaruh Pemberdayaan dan Perilaku Karyawan Terhadap Kualitas Pelayanan Perijinan SIUP Pada Dinas Perindustrian dan Perdagangan Kota Medan. Jurnal Administratur. Vol. 2. No. 1 Agustus 2008.

Sitorus, M. (2008). Pengaruh Pengawasan Terhadap Perilaku Pegawai dan Dampaknya Terhadap Kualitas Pelayanan Civil (Studi Kasus : Dinas Perdagangan dan Perindustrian Kota Medan). Ekonomi dan Bisnis Volume 2 Nomor 2 Oktober 2008.

Sitorus, M. (2009). Pengaruh Dimensi-Dimensi Pengawasan Terhadap Perilaku Pegawai (Studi Kasus : Dinas Perindustrian dan Perdagangan Kota Medan. Majalah Ilmiah UNIKOM No.1 Vol 7 Januari 2009.

Sitorus, M. (2009). Pengaruh Pemberdayaan dan Pengawasan Terhadap Perilaku Pegawai Dalam Rangka Meningkatkan Kualitas Pelayanan 
Surat Ijin Usaha Perdagangan ( (Studi Pada Dinas Perindustrian dan Perdagangan Kota Medan. Jurnal Ilmu Administrasi Vol. VI No.1 Tahun 2009 STIA LAN Bandung.2009.

Sitorus, M. (2014). Pengaruh Perilaku Aparatur Sipil Negara Terhadap Peningkatan Kualitas Pelayanan Publik (Kajian teoritis dari sudut prespektif Ilmu AdministrasiPublik). Majalah Visi. Vol 12. Tahun 2014

Sitorus, M. (2015). Memahami Perilaku Aparatur Sipil Negara. Jurnal Etika dan Pemilu. Vol 1 No.3 Oktober Jakarta. 2015

Sitorus, M. (2015). Pilkada Berintegritas. Sinar Indonesia Baru. 7 September 2015

Sugyiono. (2008). Metode Penelitian Kuantatif Kualitatf Dan RED. Bandung: ALFABETA

Tabrani. ZA. (2014). Islamic Studies dalam Pendekatan Multidisipliner (Suatu Kajian Gradual Menuju Paradigma Global). Jurnal Ilmiah Peuradeun, 2(2), 211-234.

Tabrani. ZA. (2016). Perubahan Ideologi Keislaman Turki (Analisis GeoKultur Islam dan Politik Pada Kerajaan Turki Usmani). Jurnal Edukasi: Jurnal Bimbingan Konseling, 2(2), 130-146.

Tabrani. ZA. (2016). Transpormasi Teologis Politik Demokrasi Indonesia (Telaah Singkat Tentang Masyarakat Madani dalam Wacana Pluralisme Agama di Indonesia). Al-Ijtima i- International Journal of Government and Social Science, 2(1), 41-60

Terence R. Mitchell, (1985). People in Organization An Introduction To Organizational Behavior, (Singapore: McGraw-Hill.

Thomson, John. L. (1999). A Strategy Perspective of Entrepreneurship. International Journal of Entrepreneurial Behaviour \& Research. Vol. 5. No.6. Page 279-296. MCB University Press

Undang-Undang No 15 Tahun 2011 tentang Penyelenggaraan Pemilu,

Winardi. (2005). Pemikiran Sistematik dalam Organisasi dan Manajemen. Jakarta: Rajawali Pers

Winardi. (2006). Manajemen Perubahan (Management of Change). Jakarta: PRENADA MEDIA GROUP

Winardi. (2012). Manajemen Perilaku Organisasi. Bandung: Citra Aditya Bakti.

Zainun, B. (2004). Manajemen dan Motivasi. Jakarta: Balai Aksara 